\title{
ERVING GOFFMAN Y LA SEMIOTICA DE LO COTIDIANO
}

\author{
Francesc Hernández \\ (Universitat Autònoma de Barcelona)
}

La lectura de un libro novedoso como Relaciones en público obliga al lector a un análisis detenido para incorporar sus principales aportaciones conceptuales a otras áreas de lo social. ${ }^{2}$ En el caso de Goffman, siempre hay en sus obras un resabio desconcertante. Acostumbrados, como estamos, a apreciar los libros por la densidad de las ideas que exponen, Goffman se nos presenta con una característica genuina de los científicos sociales anglosajones: expone un discurso interesante de forma literaria. Esto, que podría predisponernos al prejuicio, se convierte en un acierto, porque ailana considerablemente el trabajo del lector.

A to largo del libro, el autor recupera la vida cotidiana para el análisis sociológico. Así, las tealidades rutinarias se convierten en el centro de atención de un nuevo continente incorporado al saber científico. Es ésta una tarea de rescate de las más sutiles formas de interacción social, que nos lleva de la mano de los estudios recientes sobre el comportamiento animal aplicados al ámbito de las relaciones humanas. Ello permite profundizar en conductas, ya casi cristalizadas en el inconsciente colectivo, para darles una significación analítica y una categoría conceptual. El estudio de las «relaciones en público» consiste en incorporar al bagaje sociológico una óptica orillada por acariciar los contornos de lo que comúnmente se entiende por trivialidad.

1. Erving Goffman, Relaciones en público. Microestudios de orden páblico (Madrid: Alianza Univetsitaxia, 1979). 
La labor de Goffman, en este libro, reside en clasificar los diferentes tipos de relaciones formales e informales y en resituar su significado en un campo teórico más relevante que la propia descripción de los comportamientos sociales. Así, van sucediéndose - entre otros-m los temas relacionados con la ubicación social del individuo, la definición de un espacio personal, las agresiones entre las partes, las formas de relación rutinizadas, hasta tejer un aparato conceptual que el lector debe ir construyendo a través del discurso. Evidentemente, como decía Weber, las facetas de lo teal son inabarcables en todas sus manifestaciones. Lo real sólo se reduce por la elección racional de los elementos que el investigador considera puntual. mente significativos. La afinidad electiva es un instrumento científico que permite delimitar las múltiples formas que adoptan los fenótzenos sociales. Ésta es una limitación intrínseca que se refleja cabalmente en el libro de Goffman. Pero tiene el acierto de situar en un contexto relacional los elementos que analiza. Si no lo hiciera así, los significados perderían todo su contenido. Como ya advierte el lector, el marco de referencia de Goffman es la sociedad norteamericana.

Un aspecto muy interesante del libro consiste en interpretar las «rela. ciones en público» como una forma amplia de comunicación de significados compartidos y socialmente aceptados. El intercambio de mensajes a través del comportamiento es importante porque establece una telación compren. siva y comprensible entre el emisor y el receptor. La comunicación no verbal, gesticular o ritual expresa un tipo de interacción frecuentemente olvi. dado en los estudios sociológicos. El ámbito de la comunicación supera así el marco de las respuestas racionales para trasladarse al área de las normas, de los convencionalismos, de las muestras de aceptación, afecto o rechazo, de los contactos ocasionales, de la imagen personal o de los formulismos. Se establece entre las personas una semiótica de lo cotidiano que tiene mucho que ver con las relaciones sociales espontáneas y no codificadas. Esta ampliación del campo de la comunicación aplicada a lo concreto es útil para explicar la interacción humana, al igual que en el mundo animal, porque en ella se involucra todo el individuo y no únicamente la dicción verbal. Toda la persona, como unidad vehicular y como unidad de participación, forma parte de un contexto definido y compartido, que sirve de marco para el intercambio comunicativo de símbolos. Como puede apreciarse, la publicidad no es ajena a planteamientos de estas características.

El retorno a lo concreto, como lugar de intervención del análisis sociológico, tiene indudable interés para el estudio de la socialización. En este proceso se interiorizan los significados utilizados cotidianamente y toman cuerpo las formas de situarse ante la tealidad. No en vano, mediante la socialización, Ios individuos imitan los comportamientos adultos y repiten 
acríticamente los contenidos que les proporciona el entorno social. Es éste un camino fértil que, sin contradecir los enfoques ya institucionalizados, permite desvelar componentes del complejo entramado de las relaciones sociales. 